\title{
VARIASI JUMLAH SUDU DAN MODIFIKASI BENTUK NOSEL PADA TURBIN TURGO UNTUK PEMBANGKIT LISTRIK TENAGA MIKROHIDRO
}

\author{
Bono, Drs, S.T., M.Eng ，Suwarti, S.T., M.T. \\ Jurusan Teknik Mesin, Program Studi Teknik Konversi Energi, Politeknik Negeri Semarang \\ Jl. Prof. Sudarto, S.H., Tembalang, Seamarang, 50275, PO BOX 6199/SMS \\ Telp. (024) 7473417, 7499585, Faks (024) 7472396
}

\begin{abstract}
Abstrak
Pembangkit listrik tenaga air khususnya mikrohidro saat ini menjadi salah satu pilihan dalam mencari energi alternatif untuk menggantikan sumber energi konvensional. Penelitian ini bertujuan untuk meneliti Tubin Turgo pada Pembangkit Listrik Tenaga Mikrohidro (PLTMH) dengan variasi jumlah sudu berbentuk mangkuk berjumlah 20 buah, 19 buah, 18 buah, dan 17 buah, serta memodifikasi bentuk nosel keluaran air dengan bentuk lingkaran dan persegi. Bentuk nosel lingkaran dan persegi mempunyai luas penampang yang sama yaitu $78,5 \mathrm{~mm}^{2}$, dengan diameter pada bentuk lingkaran yaitu $10 \mathrm{~mm}$ dan pada bentuk persegi dengan panjang sisi 10,84 mm dan 7,25 mm. Pengujian dilakukan di Laboratorium Teknik Konversi Energi, dengan parameter yang diukur yaitu debit aliran air, tekanan air pada nosel, putaran poros generator, torsi, tegangan dan arus listrik output dari generator, serta suhu air. Data dari pengujian dibuat grafik karakteristik dengan bentuk hiperbolik. Hasil terbaik didapatkan pada bentuk nosel lingkaran daripada bentuk persegi. Daya Mekanik maksimum didapat pada jumlah sudu 18 nosel lingkaran sebesar 261,722 W pada putaran 851,754 rpm. Lalu pada Daya Generator maksimum didapat pada jumlah sudu 20 nosel lingkaran sebesar 145,537 W pada putaran 1076,043 rpm. Efisiensi Generator maksimum didapat pada jumlah sudu 18 nosel persegi didapatkan sebesar 59,78\% pada putaran 1037,76 rpm. Dan Efisiensi Sistem maksimum didapat pada jumlah sudu 20 nosel lingkaran sebesar 22,664 \% pada putaran 880,148 rpm. Seтиa kinerja didapat pada debit 0,00217 $\mathrm{m}^{3} / \mathrm{s}$.
\end{abstract}

Kata Kunci : Turbin Turgo, Jumlah Sudu, Variasi.

\section{PENDAHULUAN}

Pembangkit listrik tenaga air saat ini menjadi salah satu pilihan dalam memanfaatkan sumber energi, namun pemanfaatan yang ada masih menggunakan teknologi yang sederhana. Pembangkit listrik jenis ini dalam proses pembuatannya sangat ekonomis, tetapi masih dalam skala kecil. Artinya pembangkit-pembangkit seperti ini hanya mampu mencukupi pemakaian energi listrik untuk sejumlah rumah saja. Jenis pembangkit listrik tenaga air ini sering disebut microhydro atau sering juga disebut picohydro tergantung keluaran daya listrik yang dihasilkan. Teknologi ini terdiri dari komponen utama yaitu turbin air dan generator listrik (Marsudi, Djiteng. 2006). Pembangkit Listrik Tenaga Mikrohidro (PLTMH) merupakan pembangkit alternatif yang dapat digunakan untuk memaksimalkan adanya potensi air yang ada. 
Turbin Turgo merupakan salah satu jenis turbin yang dapat digunakan pada Sistem Pembangkit Listrik Tenaga Mikrohidro. Turbin Turgo dikembangkan pada tahun 1919 oleh Gilkes sebagai modifikasi turbin Pelton. Perbedaan utama antara turbin Pelton dan turbin Turgo adalah bentuk sudunya, bentuk sudu turbin Turgo adalah setengah dari bentuk sudu turbin Pelton dengan jumlah dan ukuran sudu yang sama. Selama ini bentuk luas penampang nosel yang banyak digunakan adalah bentuk lingkaran. Untuk mengetahui apakah ada pengaruh terhadap jumlah sudu yang dipasang pada runner turbin dan bentuk penampang nosel, sehingga tugas akhir ini akan dilakukan pengembangan turbin air Turgo dengan variasi jumlah sudu dengan bentuk sudu mangkuk atau bucket. Variasi jumlah sudu yang akan digunakan yaitu 17 buah, 18 buah, 19 buah dan 20 buah. Dengan melakukan modifikasi bentuk penampang nosel menjadi persegi yang memiliki luasan yang sama dengan nosel berpenampang bentuk lingkaran.

\section{TINJAUAN PUSTAKA}

\section{Pembangkit Listrik Tenaga Mikrohidro (PLTMH)}

Mikrohidro atau yang dimaksud dengan Pembangkit Listrik Tenaga Mikrohidro (PLTMH), adalah suatu pembangkit listrik skala kecil yang menggunakan tenaga air sebagai tenaga penggeraknya seperti, saluran irigasi, sungai atau air terjun alam dengan cara memanfaatkan tinggi terjunan (head) dan jumlah debit air. Mikrohidro merupakan sebuah istilah yang terdiri dari kata mikro yang berarti kecil dan hidro yang berarti air.

Secara teknis, mikrohidro memiliki tiga komponen utama yaitu air (sebagai sumber energi), turbin dan generator. Mikrohidro mendapatkan energi dari aliran air yang memiliki perbedaan ketinggian tertentu.

Pada dasarnya, mikrohidro memanfaatkan energi potensial jatuhan air (head). Semakin tinggi jatuhan air maka semakin besar energi potensial air yang dapat diubah menjadi energi listrik. Energi mekanik yang berasal dari putaran poros turbin akan diubah menjadi energi listrik oleh sebuah generator. Mikrohidro bisa memanfaatkan ketinggian air yang tidak terlalu besar, misalnya dengan ketinggian air 2.5 meter dapat dihasilkan listrik 400 watt.

\section{Turbin Air}

Secara umum turbin air adalah alat yang mengubah energi aliran air menjadi energi mekanik yaitu putaran poros. Putaran poros ini dapat dimanfaatkan untuk berbagai hal, sebagian besar putaran poros turbin air dimanfaatkan untuk memutar generator sebagai pembangkit tenaga listrik. Fungsi turbin adalah mengubah energi ketinggian air menjadi daya putaran poros. Pemilihan turbin air merupakan bagian yang sangat penting dalam perencanaan pembangunan sebuah PLTMH. Karena besarnya energi listrik yang dihasilkan sangat tergantung dari kemampuan turbin air dalam mengubah potensi tenaga air menjadi energi mekanik

\section{Turbin Turgo}

Turbin Turgo adalah salah satu jenis turbin impulse yang sering digunakan pada PLTMH yang memiliki tinggi jatuh (head) yang tinggi karena bentuk kelengkungan sudu yang tajam. Turbin Turgo dikembangkan pada tahun 1919 oleh Gilkes sebagai modifikasi Turbin Pelton.

Turbin Turgo adalah jenis turbin yang sesuai untuk menggantikan turbin Pelton nosel ganda (multinozzel) dengan head rendah maupun turbin Francis dengan head tinggi yaitu turbin Turgo dapat bekerja pada head menengah 15 meter sampai 30 meter (Anagnostopoulos dan Papantonis 2008). Anagnostopoulos dan Papantonis, (2008).

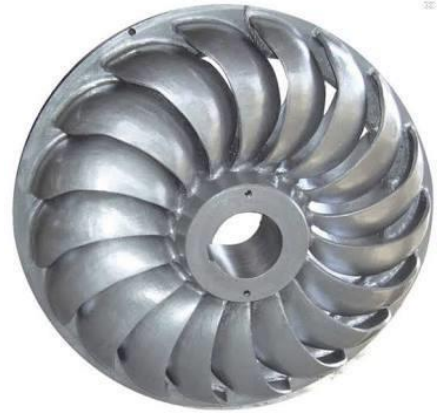

Gambar 1. Sudu Turbin Turgo

\section{Nosel}

Nosel berfungsi untuk menghasilkan jet aliran dengan cara mengubah head tekanan menjadi head kecepatan

\section{Sudu}

Sudu berfungsi seabagai penerima beban pancaran yang diseprotkan oleh nosel dan sebagai pengubah kecepatan air menjadi kecepatan sudu yang akan memutar runner yang dikopel dengan poros generator. Berikut gambar 2 yang menunjukkan penampang sudu Turbin Turgo dan segitiga kecepatan.

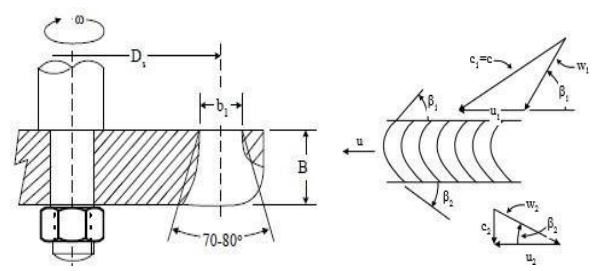

Gambar 2. Penampang sudu Turbin Turgo dan Segitiga kecepatan 


\section{Generator AC Sinkron}

Generator sinkron adalah mesin sinkron yang digunakan untuk mengubah daya mekanik menjadi daya listrik. Generator sinkron dapat berupa generator sinkron AC tiga fasa atau generator sinkron AC satu fasa tergantung dari kebutuhan. Generator sinkron memiliki jumlah putaran rotor yang sama dengan jumlah putaran medan magnet pada stator yang sama dengan jumlah putaran medan magnet pada stator sehingga diperoleh kecepatan sinkron. Kecepatan sinkron ini dihasilkan dari kecepatan putar rotor dengan kutubkutub magnet yang berputar dengan kecepatan yang sama dengan medan putar pada stator Frekuensi elektris yang dihasilkan oleh generator sinkron adalah serempak dengan kecepatan putar generator. Rotor generator sinkron terdiri atas rangkaian elektromagnet dengan suplai arus DC dimana dalam elektromagnet terdapat medan magnet. Medan magnet yang ditimbulkan oleh rotor bergerak searah putaran rotor. Hubungan antara putaran medan magnet pada mesin dengan frekuensi elektrik pada stator dapat dihitung dengan menggunakan persamaan (1) yaitu :

$n=\frac{120 f}{m}$

Keterangan :

$$
\begin{array}{lll}
\mathrm{n} & =\text { Kecepatan putar rotor } & {[\mathrm{rpm}]} \\
\mathrm{f} & =\text { Frekuensi listrik } & {[\mathrm{Hz}]} \\
\mathrm{p} & =\text { Jumlah kutub magnet } &
\end{array}
$$

\section{Landasan Teori}

\section{Rasio Kecepatan}

Rasio Kecepatan Turbin adalah perbandingan antara kecepatan keliling linier turbin pada diameter pitch runner dibagi dengan kecepatan teoritis air. Rasio Kecepatan Turbin dapat dihitung dengan persamaan (4), yaitu :

$$
\begin{aligned}
& u=\frac{\pi \cdot D_{n}}{60} \ldots \ldots . . . \\
& v=\sqrt{2 \cdot g \cdot H} \\
& \varphi=\frac{u}{v} \ldots \ldots \ldots \ldots
\end{aligned}
$$$$
\text { ( John S. Anagnostopoulos, } 2007 \text { ) }
$$

\begin{tabular}{|c|c|}
\hline$\varphi$ & $=$ rasio kecepatan \\
\hline$u$ & $=$ kecepatan sudu turbin \\
\hline$v$ & $=$ kecepatan jet teoritis \\
\hline$n$ & $=$ putaran poros \\
\hline$D_{s}$ & $=$ diameter pitch \\
\hline$H$ & $=$ head \\
\hline
\end{tabular}

( John S. Anagnostopoulos, 2007)

(John S. Anagnostopoulos, 2007 )

Keterangan :

\section{Kinerja Turbin Turgo \\ Daya Hidrolik}

Daya hidrolik adalah daya yang dimiliki oleh aliran suatu fluida (air yang dibangkitkan oleh suatu keadaan tertentu), yang dihitung dengan persamaan (5), yaitu :

$$
P_{H}=\rho \cdot g \cdot Q \cdot H
$$

( Muhammad Syawal Al-Azhar, 2017) Keterangan :

$\begin{array}{lll}\mathrm{Ph} & =\text { Daya hidrolik } & {[\mathrm{watt}]} \\ \rho & =\text { Massa jenis air } & {\left[\mathrm{kg} / \mathrm{m}^{3}\right]} \\ \mathrm{g} & =\text { Percepatan gravitasi } & {\left[\mathrm{m} / \mathrm{s}^{2}\right]} \\ \mathrm{Q} & =\text { Debit } & {\left[\mathrm{m}^{3} / \mathrm{s}\right]} \\ \mathrm{H} & =\text { Head } & {[\mathrm{m}]}\end{array}$

\section{Daya Mekanik}

Daya mekanik merupakan daya yang dihasilkan oleh poros turbin. Sehingga daya mekanik dapat dihitung pada Persamaan (6) :

$P_{\mathrm{m}}=\frac{2 \pi \mathrm{nn} T}{60}$

( Muhammad Syawal Al-Azhar, 2017)

Besarnya torsi diperoleh dengan Persamaan (7) berikut ini :

$$
\begin{aligned}
& T=F \cdot l \\
& =(m \cdot g) l \text {. } \\
& \text { Keterangan : } \\
& P_{\mathrm{m}} \quad=\text { Daya mekanik [watt] } \\
& T \quad=\text { Torsi } \quad[\mathrm{Nm}] \\
& l \quad=\text { Lengan torsi }[\mathrm{m}] \\
& m \quad=\text { Massa }[\mathrm{kg}]
\end{aligned}
$$

\section{Daya Generator}

Daya listrik yang dihasilkan oleh generator AC sinkron berupa tegangan dan arus bolak-balik yang dialirkan ke beban. Sehingga dapat dihitung Persamaan (8), yaitu :

$P_{g}=V \cdot I . \cos \varphi$.

( Sumanto, $1984: 572$ )

Keterangan :

$$
\begin{array}{lll}
P_{g} & =\text { Daya keluaran generator } & \text { [watt] } \\
V & =\text { Tegangan } & \text { [volt] } \\
l & =\text { Arus } & \text { [A] } \\
\cos \varphi & =\text { Faktor daya } &
\end{array}
$$

Dimana $\cos \varphi$ adalah perbandingan sudut fasa antara tegangan dan arus yang mempunyai nilai maksimal.

\section{Efisiensi Hidrolik}

Efisiensi hidrolik adalah perbandingan antara daya sudu dengan daya hidrolik. Sehingga dapat dihitung berdasarkan Persamaan (9), yaitu :

$\eta_{h}=\frac{P_{P_{3}}}{P_{h}} x 100 \%$

\section{Efisiensi Mekanik}

Efisiensi mekanik adalah perbandingan antara daya mekanik dengan daya sudu. Sehingga dapat dihitung berdasarkan Persamaan (10), yaitu :

$\eta_{m}=\frac{P_{m n}}{P_{x}} \times 100 \%$ 


\section{Efisiensi Generator}

Efisiensi generator adalah perbandingan antara daya generator dengan daya mekanik. Sehingga dapat dihitung berdasarkan Persamaan (11), yaitu :

$\eta_{g}=\frac{P_{g}}{P_{m}} x 100 \%$

\section{Efisiensi Sistem}

Efisiensi sistem adalah perbandingan antara daya listrik yang dihasilkan generator dengan daya hidrolik. Sehingga dapat dihitung berdasarkan Persamaan (12), yaitu :

$\eta_{s}=\frac{P_{g}}{p_{h}} \times 100 \%$

\section{METODOLOGI PELAKSANAAN}

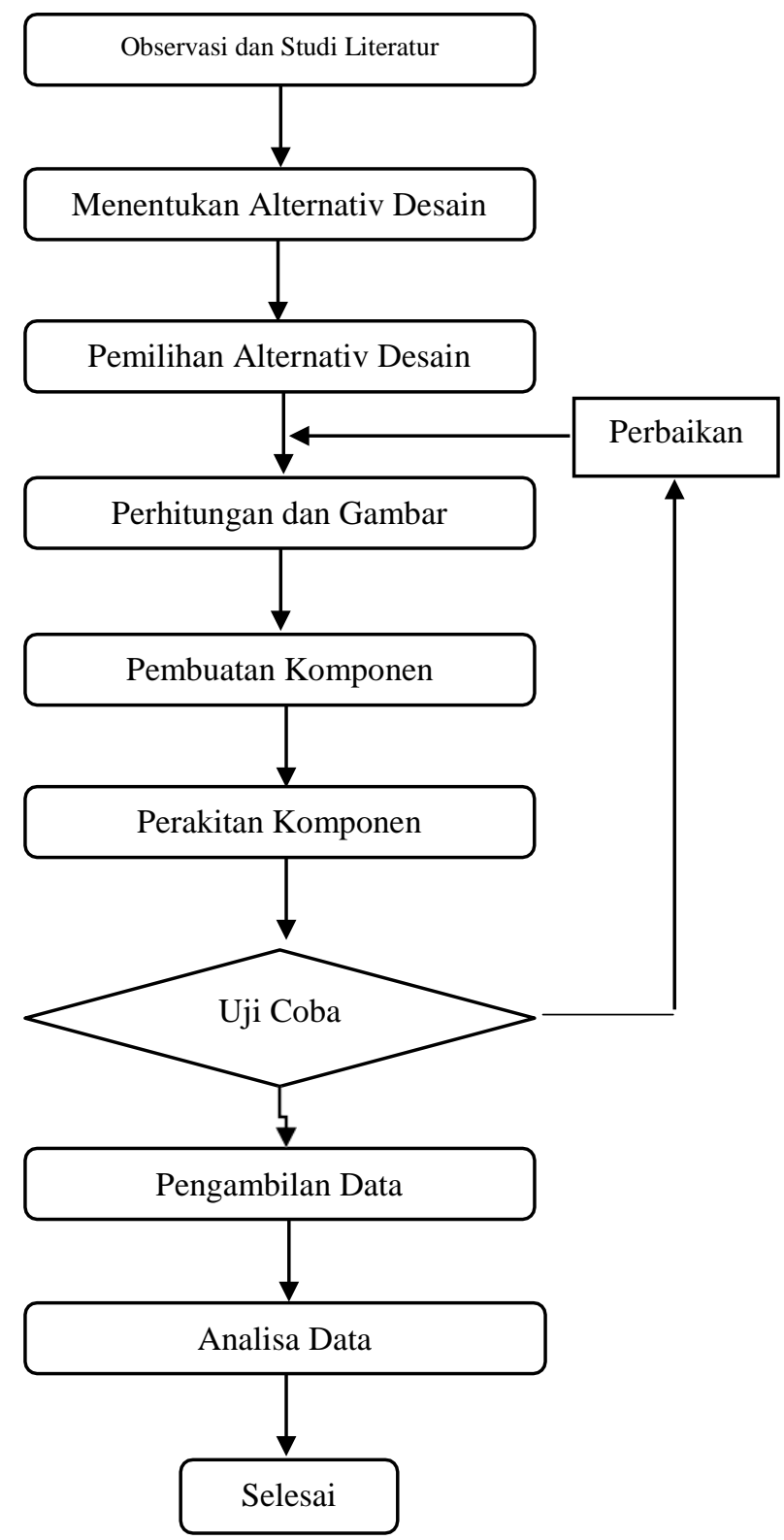

Gambar 3. Metodologi Pelaksanaan

\section{Observasi dan Studi Literatur}

Pengamatan atau observasi adalah aktivitas yang dilakukan makhluk cerdas, terhadap suatu proses atau objek dengan maksud merasakan dan kemudian memahami pengetahuan dari sebuah fenomena berdasarkan pengetahuan dan gagasan yang sudah diketahui sebelumnya, untuk mendapatkan informasi-informasi yang dibutuhkan untuk melanjutkan suatu penelitian. Ilmu pengetahuan biologi dan astronomi mempunyai dasar sejarah dalam pengamatan oleh amatir. Di dalam penelitian, observasi dapat dilakukan dengan tes, kuesioner, rekaman gambar dan rekaman suara. Studi literatur adalah mencari referensi teori yang relevan dengan kasus atau permasalahan yang ditemukan.

\section{Menentukkan Alternativ Design}

Menentukan alternatif design adalah menentukan/memutuskan pilihan lain seniterapan, arsitektur, dan berbagai pencapaian kreatif lainnya yang pada umumnya memperhitungkan aspek fungsi, estetika, dan berbagai macam aspek lainnya dengan sumber data yang didapatkan dari riset, pemikiran, brainstorming, maupun dari desain yang sudah ada sebelumnya.

\section{Pemilihan Alternativ Desain}

Pemilihan alternatif design adalah melakukan pemilihan/penentuan terhadap seni terapan, arsitektur, dan berbagai pencapaian kreatif lainnya yang pada umumnya memperhitungkan aspek fungsi, estetika, dan berbagai macam aspek lainnya dengan sumber data yang didapatkan dari riset, pemikiran, brainstorming, maupun dari desain yang sudah ada sebelumnya.

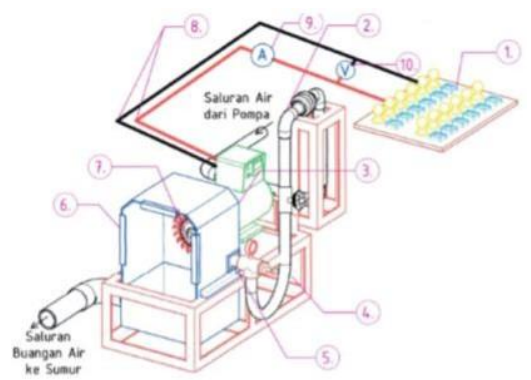

Gambar 4. Intalasi Pengujian Turbin Turgo

Keterangan:

1. Seperangkat instalasi beban berupa lampu

2. Rotameter

3. Generator

4. Saluran masukan menuju nosel

5. Nosel

6. Rumah turbin

7. Turbin turgo

8. Instalasi generator ke beban

9. Amperemeter

10. voltmeter 


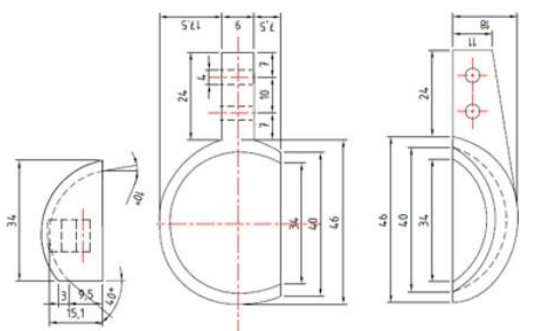

Gambar 5. Penampang Sudu Mangkuk

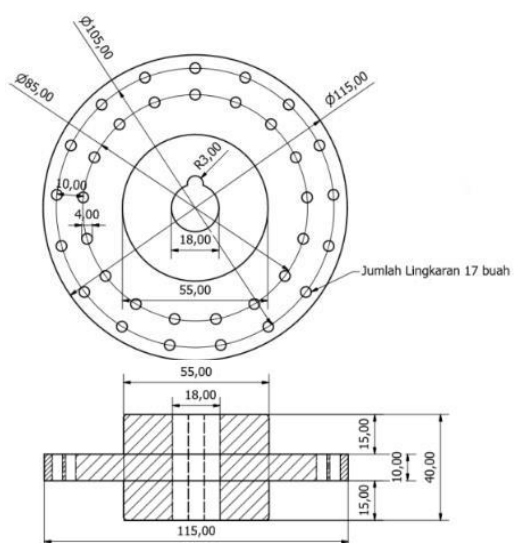

Gambar 6. Runner dengan jumlah sudu 17

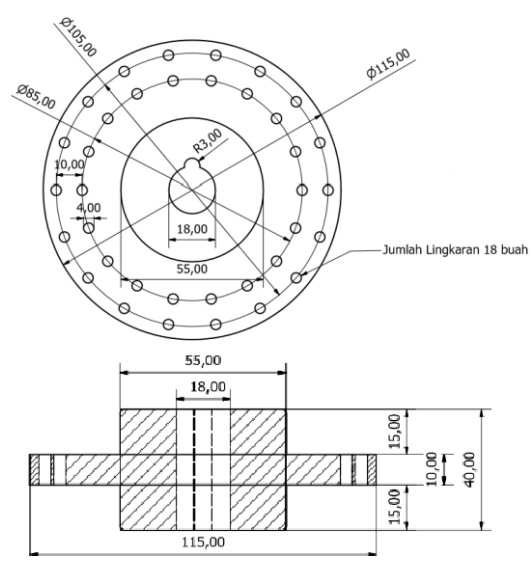

Gambar 7. Runner dengan jumlah sudu 18

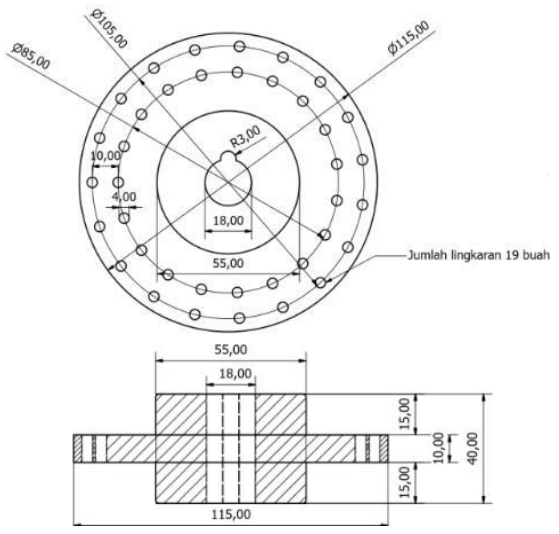

Gambar 8. Runner dengan jumlah sudu 19

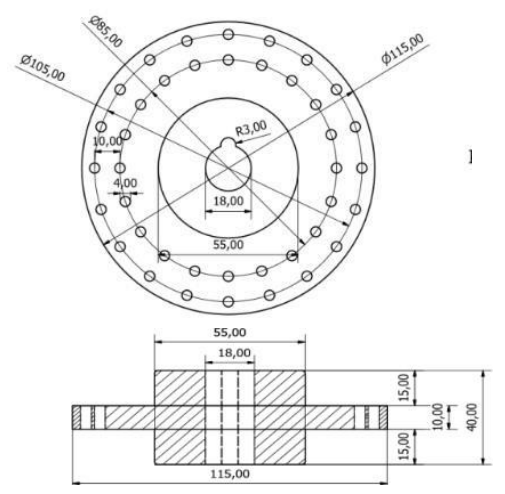

Gambar 9. Runner dengan jumlah sudu 20
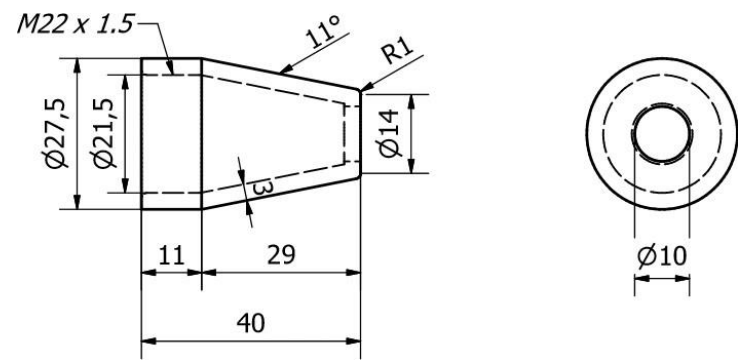

Gambar 10. Nosel dengan bentul Lingkaran
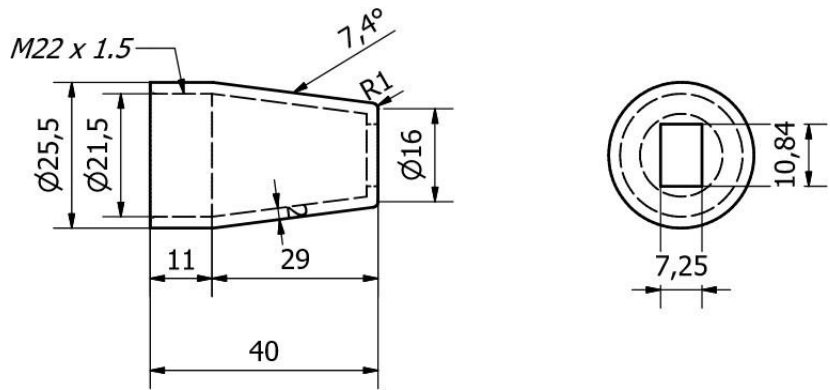

\section{Gambar 11. Nosel dengan bentuk Persegi}

\section{Penghitungan Gambar}

Penghitungan adalah adalah proses yang disengaja untuk mengubah satu masukan atau lebih ke dalam hasil tertentu, dengan sejumlah peubah. Gambar adalah kombinasi antara titik, garis, bidang, dan warna untuk menciptakan suatu imitasi dari suatu objek-biasanya objek fisik atau manusia.

\section{Pembuatan Komponen}

Pembuatan komponen adalah proses yang menghasilkan suatu komponen yaitu part-part (bagian-bagian) dari suatu produk. 


\section{Perakitan Komponen}

Perakitan komponen atau Assembling Komponen merupakan proses penggabungan/penyatuan komponen-komponen menjadi satu kesatuan yang utuh

\section{Uji Coba}

Uji coba adalah proses pengujian sesuatu sebelum dipakai atau dilaksanakan seperti bahan tes, kendaraan, dan lain-lain.

\section{Pengambilan Data}

Pengambilan data adalah teknik atau cara yang dilakukan oleh peneliti untuk mengumpulkan data. Pengumpulan data dilakukan untuk memperoleh informasi yang dibutuhkan dalam rangka mencapai tujuan penelitian. Sementara itu instrumen pengumpulan data merupakan alat yang digunakan untuk mengumpulkan data. Karena berupa alat, maka instrumen pengumpulan data dapat berupa check list, kuesioner, pedoman wawancara, hingga kamera untuk foto atau untuk merekam gambar

\section{Analisa Data}

Analisa data adalah Kegiatan mengubah data hasil penelitian menjadi informasi yang dapat digunakan untuk mengambil kesimpulan dalam suatu penelitian. Adapun cara mengambil kesimpulan bisa dengan hipotesis maupun dengan estimasi hasil.

\section{HASIL DAN PEMBAHASAN}

Pelaksanaan langkah pengujian adalah sebagai berikut :

1. Menyiapkan instalasi pengujian turbin Turgo.

2. Menyiapakan peralatan yang dibutuhkan antara lain tachometer, torsimeter, voltmeter, amperemeter, multimeter, kabel spade, themometer, load bank dan kunci pas.

3. Memasang runner dengan sudu berjumlah 20 buah berbentuk mangkuk pada instalasi.

4. Mengisi bak tampungan air.

5. Memasang nosel berbentuk lingkaran dan mengatur sudut nosel $20^{\circ}$ agar semprotan nosel mengenai sudu-sudu turbin Turgo.

6. Menghubungkan voltmeter secara paralel pada generator untuk mengukur tegangan yang dihasilkan.

7. Menghubungkan amperemeter secara seri pada generator dan beban untuk mengukur arus yang melewati beban.

8. Meng-ON kan pompa

9. Mengatur katup bypass dan katup bukaan nosel mencapai tekanan 3 bar yang terukur pada manometer dan debit 130 liter/menit yang terukur pada rotameter.

10. Menaikan beban pada loadbank secara bertahap dari $10 \mathrm{~W}$ hingga $600 \mathrm{~W}$.

11. Mengukur putaran poros generator menggunakan tachometer
12. Mengukur torsi menggunakan neraca pegas digital

13. Mencatat data-data yang diperlukan pada tabel

14. Setelah selesai mencatat seluruh data yang diperlukan, matikan beban secara bertahap dan meng-OFF kan pompa

15. Mengulangi langkah no. 8 sampai 14 dengan mengganti sudu mangkuk berjumlah 19,18 , dan 17 buah.

16. Mengulangi langkah no. 8 sampai 14 dengan tekanan tetap 3 bar dan debit 115 liter/menit.

17. Mengulangi langkah no. 8 sampai 16 dengan bentuk nosel persegi.

\section{DATA HASIL PENGUJIAN}

Data Hasil Pengujian Runner Sudu Berjumlah 20 Buah Berbentuk Mangkuk dengan Nosel Berbentuk Lingkaran pada Tekanan Air Masuk Nosel 3 Bar dan Debit 130 liter/menit pada Tabel 1.

Tabel 1 Data Hasil Pengujian Runner Sudu Berjumlah 20 Buah Berbentuk Mangkuk dengan Nosel Berbentuk Lingkaran pada Tekanan Air Masuk Nosel 3 Bar dan Debit 130 liter/menit.

\begin{tabular}{|c|c|c|c|c|c|}
\hline No & $\begin{array}{c}\text { Beban } \\
(\mathbf{W})\end{array}$ & $\begin{array}{c}\mathbf{N} \\
(\mathbf{r p m})\end{array}$ & $\begin{array}{c}\text { Torsi } \\
(\mathbf{k g})\end{array}$ & $\begin{array}{c}\text { Tegangan } \\
(\mathbf{V})\end{array}$ & $\begin{array}{c}\text { Arus } \\
(\mathbf{A})\end{array}$ \\
\hline 1 & 0 & 1680 & 0,25 & 246 & 0 \\
\hline 2 & 10 & 1660 & 0,275 & 243 & 0,1 \\
\hline 3 & 20 & 1638 & 0,28 & 237 & 0,2 \\
\hline 4 & 30 & 1632 & 0,29 & 235,5 & 0,21 \\
\hline 5 & 40 & 1602 & 0,295 & 231 & 0,22 \\
\hline 6 & 50 & 1580 & 0,305 & 228 & 0,28 \\
\hline 7 & 60 & 1568 & 0,31 & 226,5 & 0,3 \\
\hline 8 & 70 & 1552 & 0,315 & 223,5 & 0,34 \\
\hline 9 & 80 & 1502 & 0,325 & 216 & 0,4 \\
\hline 10 & 90 & 1498 & 0,34 & 214,5 & 0,4 \\
\hline 11 & 100 & 1490 & 0,355 & 213 & 0,44 \\
\hline 12 & 110 & 1458 & 0,36 & 207 & 0,48 \\
\hline 13 & 120 & 1426 & 0,385 & 199,5 & 0,54 \\
\hline 14 & 130 & 1422 & 0,39 & 198 & 0,6 \\
\hline 15 & 140 & 1412 & 0,385 & 193,5 & 0,58 \\
\hline 16 & 150 & 1378 & 0,39 & 192 & 0,63 \\
\hline 17 & 160 & 1368 & 0,395 & 189 & 0,64 \\
\hline 18 & 170 & 1356 & 0,405 & 186 & 0,68 \\
\hline 19 & 180 & 1338 & 0,415 & 181,5 & 0,73 \\
\hline 20 & 190 & 1318 & 0,42 & 178,5 & 0,74 \\
\hline 21 & 200 & 1310 & 0,425 & 177 & 0,76 \\
\hline 22 & 210 & 1270 & 0,465 & 174 & 0,8 \\
\hline 23 & 220 & 1246 & 0,495 & 171 & 0,86 \\
\hline 24 & 230 & 1240 & 0,515 & 169,5 & 0,86 \\
\hline 25 & 240 & 1230 & 0,53 & 162 & 0,88 \\
\hline 26 & 250 & 1210 & 0,545 & 159 & 0,9 \\
\hline 27 & 260 & 1168 & 0,565 & 147 & 0,93 \\
\hline 28 & 270 & 1162 & 0,565 & 145,5 & 0,94 \\
\hline 29 & 280 & 1156 & 0,555 & 144 & 0,96 \\
\hline 30 & 290 & 1128 & 0,56 & 139,5 & 0,98 \\
\hline
\end{tabular}


Tabel 1 Lanjutan

\begin{tabular}{|c|c|c|c|c|c|}
\hline No & $\begin{array}{l}\text { Beban } \\
\text { (W) }\end{array}$ & $\begin{array}{c}\mathrm{N} \\
(\mathrm{rpm})\end{array}$ & $\begin{array}{l}\text { Torsi } \\
\text { (kg) }\end{array}$ & $\begin{array}{c}\text { Tegangan } \\
\text { (V) }\end{array}$ & $\begin{array}{l}\text { Arus } \\
\text { (A) }\end{array}$ \\
\hline 31 & 300 & 1110 & 0,575 & 138 & 1 \\
\hline 32 & 310 & 1090 & 0,605 & 135 & 1,04 \\
\hline 33 & 320 & 1066 & 0,605 & 130,5 & 1,07 \\
\hline 34 & 330 & 1038 & 0,61 & 129 & 1,08 \\
\hline 35 & 340 & 1016 & 0,6 & 129 & 1,08 \\
\hline 36 & 350 & 1004 & 0,615 & 123 & 1,12 \\
\hline 37 & 360 & 984 & 0,64 & 120 & 1,15 \\
\hline 38 & 370 & 952 & 0,645 & 118,5 & 1,16 \\
\hline 39 & 380 & 950 & 0,665 & 117 & 1,18 \\
\hline 40 & 390 & 940 & 0,67 & 114 & 1,2 \\
\hline 41 & 400 & 936 & 0,68 & 112,5 & 1,2 \\
\hline 42 & 410 & 916 & 0,68 & 111 & 1,22 \\
\hline 43 & 420 & 906 & 0,69 & 108 & 1,24 \\
\hline 44 & 430 & 904 & 0,69 & 106,5 & 1,25 \\
\hline 45 & 440 & 880 & 0,695 & 105 & 1,27 \\
\hline 46 & 450 & 874 & 0,705 & 103,5 & 1,3 \\
\hline 47 & 460 & 858 & 0,715 & 102 & 1,32 \\
\hline 48 & 470 & 856 & 0,705 & 100,5 & 1,32 \\
\hline 49 & 480 & 850 & 0,715 & 99 & 1,34 \\
\hline 50 & 490 & 842 & 0,725 & 96 & 1,36 \\
\hline 51 & 500 & 840 & 0,73 & 94,5 & 1,38 \\
\hline 52 & 510 & 828 & 0,73 & 93 & 1,39 \\
\hline 53 & 520 & 822 & 0,735 & 91,5 & 1,4 \\
\hline 54 & 530 & 816 & 0,735 & 90 & 1,4 \\
\hline 55 & 540 & 804 & 0,75 & 88,5 & 1,42 \\
\hline 56 & 550 & 800 & 0,755 & 87 & 1,44 \\
\hline 57 & 560 & 800 & 0,745 & 84 & 1,5 \\
\hline 58 & 570 & 792 & 0,765 & 78 & 1,56 \\
\hline 59 & 580 & 790 & 0,75 & 75 & 1,58 \\
\hline 60 & 590 & 788 & 0,75 & 75 & 1,59 \\
\hline 61 & 600 & 780 & 0,75 & 73,5 & 1,6 \\
\hline
\end{tabular}

Berdasarkan data hasil pengujian yang diperoleh seperti pada tabel hasil pengujian maka dapat dihitung besaran daya hidrolik, daya mekanik, daya listrik (daya generator), efisiensi turbin, efisiensi generator dan efisiensi sistem PLTMH. Contoh perhitungan pada sudu berjumlah 20 buah berbentuk mangkuk dengan nosel berbentuk lingkaran pada tekanan air masuk nosel sebesar 3 bar dan debit 130 liter/menit pada beban nominal lampu 100 Watt dengan data sebagai berikut:
1. $\operatorname{Debit}(\mathrm{Q})$
$=130 \mathrm{l} / \mathrm{menit}$
2. Tekanan $(\mathrm{P})$
$=3 \mathrm{bar}$
$=1490 \mathrm{rpm}$
3. Putaran (n)
4. Torsi (T)
5. Tegangan $(\mathrm{V})$
$=1,392 \mathrm{~kg}$
$=213 \mathrm{~V}$
$=0,44 \mathrm{~A}$
$=30 \mathrm{C}$
7. Suhu air
$=0,4 \mathrm{~m}$
$=0,135 \mathrm{~m}$

\section{Mencari Head}

Head yang diperoleh merupakan hasil konversi dari pembacaan alat ukur manometer dari bar menjadi $\mathrm{mH} 2 \mathrm{O}$, yaitu :

Dari tabel konversi diperoleh bahwa
1 bar $=10,197 \mathrm{mH} 2 \mathrm{O}$

$H=3$ bar $=3$ bar $x 10,197 \frac{\mathrm{mH}_{2} \mathrm{O}}{\mathrm{bar}}=30,6 \mathrm{mH}_{2} \mathrm{O}$

\section{Mencari Debit}

Perhitungan debit ini merupakan hasil konversi dari hasil pembacaan alat ukur rotameter dari liter/menit menjadi $\mathrm{m}^{3} / \mathrm{s}$, yaitu :

$Q=130 \frac{l}{\text { menit }}=\frac{130 \frac{l}{\text { menit }}}{1000 \times 60 \frac{\mathrm{s}}{\text { menit }}}=0,00217 \frac{\mathrm{m}^{3}}{\mathrm{~s}}$

\section{Mencari Kecepatan Sudu Turbin}

Untuk mencari kecepatan sudu turbin berdasarkan Persamaan (2), yaitu :

$u=\frac{\pi x n D_{i}}{60}$

$u=\frac{3,14 x 1490 x 0,135}{600}$

$u=10,53 \frac{60}{g}$

\section{Mencari Kecepatan Jet Teoritis}

Untuk mencari kecepatan pancaran jet teoritis dengan Persamaan (3), sebagai berikut :

$$
\begin{aligned}
\nu & =\sqrt{2 g H} \\
& =\sqrt{2.9,806.30,6} \\
& =24,5 \frac{\mathrm{m}}{\mathrm{s}}
\end{aligned}
$$

\section{Mencari Rasio Kecepatan}

Perhitungan rasio kecepatan sesuai dengan Persamaan (4), yaitu :

$\varphi=\frac{u}{v}$

$\varphi=\frac{10,5 a}{24,5}=0,43$

\section{Mencari Torsi}

Besarnya torsi dapat dihitung sesuai dengan

Persamaan (7), yaitu :

$$
\begin{aligned}
T & =F x l \\
& =(m x g) x l \\
& =0,355 \mathrm{~kg} x 9,806 \frac{\mathrm{m}}{\mathrm{s}^{2} x} 0,4 \mathrm{~m} \\
& ={ }_{1}, 392 \mathrm{Nm}
\end{aligned}
$$

\section{Mencari Daya Input (Hidrolik)}

Perhitungan daya hidrolik sesuai dengan Persamaan (5), yaitu :

$$
\begin{aligned}
P_{\mathrm{g} 0} \mathrm{C} & =995,944 \frac{\mathrm{kg}}{\mathrm{m}^{3}} \\
P_{\mathrm{h}} & =\rho \cdot g \cdot Q \cdot h \\
& =995,944 \frac{\mathrm{kg}}{\mathrm{m}^{3}} \times 9,806 \frac{\mathrm{m}}{\mathrm{s}^{2} x} 0,00217 \frac{\mathrm{m}^{3}}{\mathrm{~s}} \times 30,6 \mathrm{~m} \\
& =648,497 \mathrm{~W}
\end{aligned}
$$

\section{Mencari Daya Mekanik}

Perhitungan daya mekanik sesuai dengan Persamaan (6), yaitu :

$P_{m}=\frac{2 \pi m x}{60}$ 


$$
\begin{aligned}
& =\frac{2 \cdot 3,14 \cdot 1490 \cdot 1,392}{60} \\
& =217,158 \mathrm{~W}
\end{aligned}
$$

9. Mencari Daya Listrik (Daya Generator) Perhitungan daya generator sesuai dengan Persamaan (8), yaitu :

$$
\begin{aligned}
P_{g} & =V \cdot I \cdot \cos \varphi \\
& =213 \cdot 0,44.1 \\
& =93,72 \mathrm{~W}
\end{aligned}
$$

\section{Mencari Efisiensi Turbin}

Perhitungan efisiensi turbin sesuai dengan Persamaan di bawah ini, yaitu :

$$
\begin{aligned}
\eta_{t} & =\frac{P_{h \pi}}{P_{h}} x 100 \% \\
& =\frac{217,158}{649,497} \times 100 \% \\
& =33,49 \%
\end{aligned}
$$

11. Mencari Efisiensi Generator Perhitungan efisiensi generator sesuai dengan Persamaan (11), yaitu :

$$
\begin{aligned}
\eta_{g} & =\frac{P_{g}}{P_{\pi}} \times 100 \% \\
& =\frac{99.72}{217,158} \times 100 \% \\
& =43,16 \%
\end{aligned}
$$

\section{Mencari Efisiensi Sistem}

Perhitungan efisiensi turbin sesuai dengan Persamaan (12), yaitu :

$$
\begin{aligned}
\eta_{s} & =\frac{P_{g}}{P_{h}} \times 100 \% \\
& =\frac{98,72}{648,497} \times 100 \% \\
& =14,45
\end{aligned}
$$

\begin{tabular}{|c|c|c|c|c|c|c|c|c|}
\hline No & $\begin{array}{l}\text { Beban } \\
\text { (W) }\end{array}$ & $\begin{array}{c}\mathrm{N} \\
(\mathrm{rpm})\end{array}$ & $\begin{array}{l}\text { Ph } \\
\text { (W) }\end{array}$ & $\begin{array}{l}\mathrm{Pm} \\
\text { (W) }\end{array}$ & $\begin{array}{l}\mathrm{Pg} \\
\text { (W) }\end{array}$ & $\begin{array}{c}\eta \\
(\%)\end{array}$ & $\begin{array}{c}\eta_{k} \\
(\%)\end{array}$ & $\begin{array}{c}\eta_{r} \\
(\%)\end{array}$ \\
\hline & & 26 & 3,497 & 5,393 & 07,73 & 4,76 & 7,80 & \\
\hline & & 22 & 8,497 & 7,680 & 118,8 & & & \\
\hline 15 & & 12 & 4,497 & 3,180 & 112,23 & 41 & & 731 \\
\hline 16 & & 378 & 8,497 & 220,635 & 120,96 & 34,02 & 4,82 & 18,65 \\
\hline 17 & 160 & 1368 & 648,497 & 221,842 & 120,96 & 34,21 & 54,53 & 18,65 \\
\hline 18 & & 356 & 488,497 & 225,463 & 126,48 & 34,77 & 56,10 & 19,50 \\
\hline 1 & 30 & 338 & 648,497 & 227,963 & 132,495 & 35,15 & 58,12 & 20,43 \\
\hline 20 & 90 & 318 & 648,497 & 227,261 & 132,09 & 5,04 & 58,12 & 0,37 \\
\hline 21 & 200 & 1310 & 648,497 & 228,571 & 134,52 & 35,25 & 58,85 & 20,74 \\
\hline 22 & 210 & 1270 & 648,497 & 242,447 & 139,2 & 37,39 & 57,41 & 21,47 \\
\hline 23 & 0 & 1246 & 648,497 & 253,212 & 147,06 & 39,05 & 58,08 & 22,68 \\
\hline 24 & 230 & 1240 & 648,497 & 262,174 & 145,77 & 40,43 & 55,60 & 22,48 \\
\hline 25 & 240 & 1230 & 648,497 & 267,634 & 142,56 & 41,27 & 53,27 & 21,98 \\
\hline 26 & & 210 & 648,497 & 270,734 & 143,1 & 1,75 & 52,86 & 2,07 \\
\hline 27 & 260 & 1168 & 648,497 & 270,927 & 136,71 & 41,78 & 50,46 & 21,08 \\
\hline 28 & 270 & 1162 & 648,497 & 269,535 & 136,77 & 41,56 & 50,74 & 21,09 \\
\hline 29 & 30 & 1156 & 648,497 & 263,397 & 138,24 & 40,62 & 52,48 & 21,32 \\
\hline 30 & 290 & 1128 & 648,497 & 259,333 & 136,71 & 39,99 & 52,72 & 21,08 \\
\hline 31 & 300 & 1110 & 648,497 & 262,030 & 138 & 40,41 & 52,67 & 21,28 \\
\hline 32 & 310 & 1090 & 648,497 & 270,734 & 140,4 & 41,75 & 51,86 & 21,65 \\
\hline 33 & 320 & 1066 & 648,497 & 264,772 & 139,635 & 40,83 & 52,74 & 21,53 \\
\hline 34 & 330 & 1038 & 648,497 & 259,949 & 139,32 & 40,08 & 53,60 & 21,48 \\
\hline 35 & 340 & 1016 & 648,497 & 250,268 & 139,32 & 38,59 & 55,67 & 21,48 \\
\hline 36 & 350 & 1004 & 648,497 & 253,495 & 137,76 & 39,09 & 54,34 & 21,24 \\
\hline 37 & 360 & 984 & 648,497 & 258,545 & 138 & 39,87 & 53,38 & 21,28 \\
\hline 38 & 370 & 952 & 648,497 & 252,091 & 137,46 & 38,87 & 54,53 & 21,20 \\
\hline 39 & 380 & 950 & 648,497 & 259,362 & 138,06 & 39,99 & 53,23 & 21,29 \\
\hline 40 & 390 & 940 & 648,497 & 258,561 & 136,8 & 39,87 & 52,91 & 21,09 \\
\hline 41 & 400 & 936 & 648,497 & 261,303 & 135 & 40,29 & 51,66 & 20,82 \\
\hline 42 & 410 & 916 & 648,497 & 255,720 & 135,42 & 39,43 & 52,96 & 20,88 \\
\hline 43 & 420 & 906 & 648,497 & 256,648 & 133,92 & 39,58 & 52,18 & 20,65 \\
\hline 44 & 430 & 904 & 648,497 & 256,081 & 133,125 & 39,49 & 51,99 & 20,53 \\
\hline 45 & 4 & 880 & 648,497 & 251,089 & 133,35 & 38,72 & 53,11 & 20,56 \\
\hline 46 & 4. & 874 & 4997 & 252,965 & 134,55 & 39,01 & 53,19 & 20,75 \\
\hline 47 & 460 & 5 & 648,497 & 251,857 & 134,64 & 38,84 & 53,46 & 20,76 \\
\hline 48 & 470 & 856 & 648,497 & 247,755 & 132,66 & 38,20 & 53,54 & 20,46 \\
\hline 49 & 480 & 850 & 648,497 & 249,508 & 132,66 & 38,47 & 53,17 & 20,46 \\
\hline 50 & 490 & 842 & 648,497 & 250,617 & 130,56 & 38,65 & 52,10 & 20,13 \\
\hline 51 & 500 & 840 & 648,497 & 251,746 & 130,41 & 38,82 & 51,80 & 20,11 \\
\hline 52 & 510 & 828 & 648,497 & 248,150 & 129,27 & 38,27 & 52,09 & 19,93 \\
\hline 53 & 520 & 822 & 648,497 & 248,039 & 128,1 & 38,25 & 51,65 & 19,75 \\
\hline 54 & 530 & 816 & 648,497 & 246,228 & 126 & 37,97 & 51,17 & 19,43 \\
\hline$\overline{55}$ & 540 & 804 & ,497 & 247,558 & 125,67 & 38,17 & 50,76 & 19,38 \\
\hline 56 & 550 & 800 & 648,497 & 247,969 & 125,28 & 38,24 & 50,52 & 19,32 \\
\hline 57 & 560 & 800 & 648,497 & 244,685 & 126 & 37,73 & 51,49 & 19,43 \\
\hline 58 & 570 & 792 & 648,497 & 248,741 & 121,68 & 38,36 & 48,92 & 18,76 \\
\hline 59 & 580 & 790 & 648,497 & 243,248 & 118,5 & 37,51 & 48,72 & 18,27 \\
\hline 60 & 590 & 788 & 648,497 & 242,632 & 119,25 & 37,41 & 49,15 & 18,39 \\
\hline 6 & 600 & 780 & 648,497 & 240,169 & \begin{tabular}{ll|}
117,6 \\
\end{tabular} & 37,03 & 48,97 & 18,13 \\
\hline
\end{tabular}

Untuk data selanjutnya dapat dihitung dengan menggunakan persamaan yang sama dan hasil perhitungan dapat disajikan pada Tabel 2 sebagai berikut ini.

Tabel 2 Data Hasil Perhitungan Runner Sudu Berjumlah 20 Buah Berbentuk Mangkuk dengan Nosel Berbentuk Lingkaran pada Tekanan Air Masuk Nosel 3 Bar dan Debit 130 liter/menit.

\begin{tabular}{|c|c|c|c|c|c|c|c|r|}
\hline No & $\begin{array}{c}\text { Beban } \\
\text { (W) }\end{array}$ & $\begin{array}{c}\text { N } \\
(\mathbf{r p m})\end{array}$ & $\begin{array}{c}\text { Ph } \\
\text { (W) }\end{array}$ & $\begin{array}{c}\text { Pm } \\
\text { (W) }\end{array}$ & $\begin{array}{c}\text { Pg } \\
\text { (W) }\end{array}$ & $\begin{array}{c}\boldsymbol{\eta} \\
(\%)\end{array}$ & $\begin{array}{c}\boldsymbol{\eta}_{\mathbf{z}} \\
(\%)\end{array}$ & $\begin{array}{c}\boldsymbol{\eta} \\
(\%)\end{array}$ \\
\hline 1 & 0 & 1680 & 648,497 & 172,429 & 0 & 26,59 & 0 & 0 \\
\hline 2 & 10 & 1660 & 648,497 & 187,414 & 24,3 & 28,90 & 12,97 & 3,75 \\
\hline 3 & 20 & 1638 & 648,497 & 188,292 & 47,4 & 29,04 & 25,17 & 7,31 \\
\hline 4 & 30 & 1632 & 648,497 & 194,303 & 49,455 & 29,96 & 25,45 & 7,63 \\
\hline 5 & 40 & 1602 & 648,497 & 194,019 & 50,82 & 29,92 & 26,19 & 7,84 \\
\hline 6 & 50 & 1580 & 648,497 & 197,841 & 63,84 & 30,51 & 32,27 & 9,84 \\
\hline 7 & 60 & 1568 & 648,497 & 199,557 & 67,95 & 30,77 & 34,05 & 10,48 \\
\hline 8 & 70 & 1552 & 648,497 & 200,707 & 75,99 & 30,95 & 37,86 & 11,72 \\
\hline 9 & 80 & 1502 & 648,497 & 200,407 & 86,4 & 30,90 & 43,11 & 13,32 \\
\hline 10 & 90 & 1498 & 648,497 & 209,099 & 85,8 & 32,24 & 41,03 & 13,23 \\
\hline
\end{tabular}

Tabel 2 Lanjutan 


\section{ANALISA DATA HASIL PENGUJIAN}

Grafik dibuat untuk mempermudah analisa data hasil pengujian. Pada Tugas Akhir ini dilakukan uji kinerja turbin Turgo sudu berbentuk mangkuk dengan nosel berbentuk lingkaran dan nosel persegi pada saat variasi jumlah sudu 20, 19, 18, dan 17. Pengujian variasi jumlah sudu dengan nosel berbentuk lingkaran dan nosel persegi ini diuji pada tekanan air masuk nosel 3 bar dan debit 130 liter/menit, kemudian diperoleh hasil berupa contoh grafik sebagai berikut :

\section{Karakteristik Daya Mekanik (Pm) terhadap Putaran (n)}

Gambar 11. dibawah ini menunjukkan karakteristik hubungan daya mekanik terhadap putaran saat menggunakan nosel lingkaran. Pengujian dengan variasi jumlah sudu mangkuk yaitu pada sudu 20, 19, 18, dan 17 buah menghasilkan 4 kurva berbeda. Pada masingmasing sudu diuji pada head sebesar 3 bar dan debit sebesar 130 liter/menit menunjukkan sifat atau kecenderungan yang sama pula yaitu daya mekanik meningkat bersamaan dengan naiknya putaran poros hingga mencapai titik puncaknya yang kemudian akan turun kembali meskipun putaran nya terus meningkat

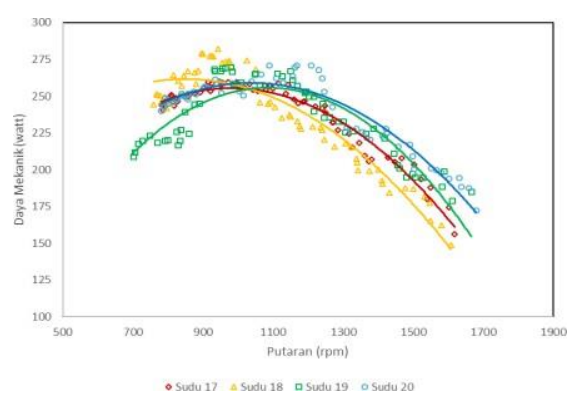

\section{Gambar 12. Grafik Hubungan Daya Mekanik (Pm) terhadap Putaran (n) menggunakan Nosel Lingkaran}

Berdasarkan Gambar 11. tersebut harga optimum kurva karakteristik daya mekanik terhadap putaran berturut-turut adalah sudu 18, 20, 19, dan 17.

Selanjutnya untuk masing-masing sudu memberikan daya mekanik maksimum sebagai berikut :

1. Jumlah sudu 18 buah diperoleh nilai maksimum daya mekanik sebesar $261,722 \mathrm{~W}$ pada putaran $851,754 \mathrm{rpm}$.

2. Harga maksimum daya mekanik pada jumlah sudu 20 buah diperoleh sebesar 259,378 W pada putaran 1040,637 rpm.

3. Harga maksimum jumlah sudu 17 buah diperoleh daya mekanik maksimum sebesar $255,807 \mathrm{~W}$ pada putaran $983,127 \mathrm{rpm}$.
4. Sedangkan untuk jumlah sudu 19 buah diperoleh sebesar $255,514 \mathrm{~W}$ pada putaran $1084,467 \mathrm{rpm}$.

Hasil nilai daya mekanik optimum diatas tidak hanya dipengaruhi oleh banyaknya jumlah sudu mangkuk yang ada tapi juga kerapatan sudut antara sudu pada runner turbin, dan pengaruh dari menggunakan nosel lingkaran.

\section{Karakteristik Daya Generator (Pg) Terhadap Putaran (n)}

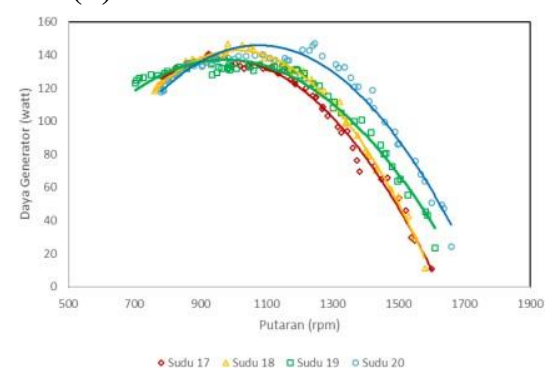

\section{Gambar 13. Grafik Hubungan Daya \\ Generator (Pg) terhadap Putaran (n) menggunakan Nosel Lingkaran}

Gambar 12. terlihat bahwa grafik hubungan daya generator terhadap putaran pada keempat kurva pada sudu 20,19, 18, dan 17 buah menunjukkan semakin putaran runner bertambah maka daya generator naik hingga titik puncak, kemudian daya generator turun walaupun putaran terus bertambah sehingga membentuk kurva hiperbolik. Adapun harga kurva optimum maksimum berturut-turut sebagai berikut:

1. Sudu 20 diperoleh daya generator maksimum sebesar 145,537 W pada putaran 1076,043 rpm.

2. Daya generator maksimum untuk sudu 18 diperoleh sebesar 143,099 W pada putaran 1012,085 rpm.

3. Daya generator maksimum untuk sudu 17 diperoleh sebesar 137,286 W pada putaran 970,761 rpm.

4. Sedangkan pada sudu 19 diperoleh daya generator maksimum sebesar $136,744 \mathrm{~W}$ pada putaran 972,804 rpm.

\section{Karakteristik Efisiensi Generator $\left(\eta_{\mathrm{g}}\right)$ terhadap Putaran (n)}

Gambar 13 dibawah ini adalah grafik hubungan antara efisiensi generator terhadap putaran menggunakan nosel lingkaran. Pengujian dilakukan pada sudu berjumlah $20,19,18$, dan 17 pada head 3 bar dan debit $130 \mathrm{lpm}$, kemudian diperoleh 4 kurva berbeda dengan harga efisiensi generator yang berbeda pula. Putaran yang dihasilkan oleh masing-masing sudu yang berbeda berpengaruh pada harga efisiensi yang diperoleh. Semakin cepat putaran runner sudu maka harga efisiensi semakin 
tinggi hingga titik puncak, dan kemudian turun meskipun putaran semakin bertambah.

Berdasarkan data efisiensi generator pada masingmasing sudu diperoleh efisiensi generator terbaik berturut-turut adalah efisiensi generator sebesar $57,00 \%$ dengan putaran sebesar 1058,156 diperoleh dari sudu 18, sudu 20 efisiensi turbinnya sebesar $56,89 \%$ pada putaran $1088,116 \mathrm{rpm}$, sudu 19 diperoleh efisiensi sebesar $56,64 \%$ pada putaran $826,061 \mathrm{rpm}$, dan sudu 17 dengan efisiensi turbin sebesar $54,7 \%$ pada putaran $983,151 \mathrm{rpm}$.

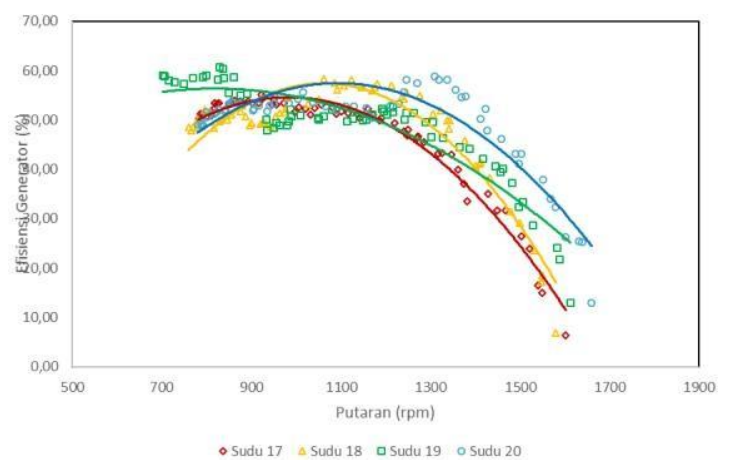

Gambar 14. Grafik Hubungan Efisiensi Generator terhadap Putaran menggunakan Nosel Lingkaran

\section{Karakteristik Efisiensi Sistem $\left(\eta_{\mathrm{s}}\right)$ terhadap Putaran (n)}

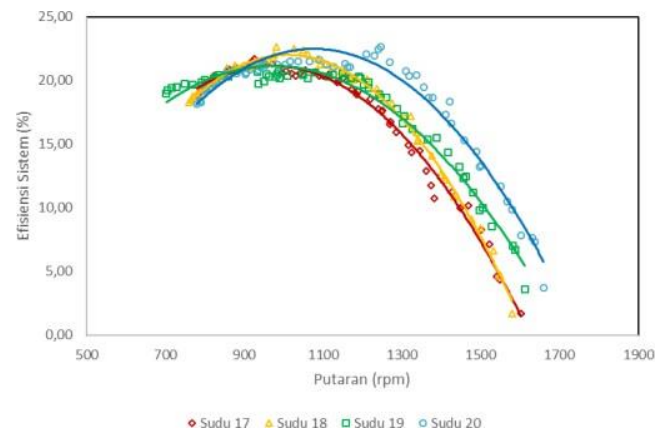

\section{Gambar 15. Grafik Hubungan Efisiensi Sistem terhadap Putaran menggunakan Nosel Lingkaran}

Gambar 14. diatas menunjukkan karakteristik hubungan efisiensi sistem terhadap putaran menggunakan Nosel lingkaran.Variasi jumlah sudu yaitu sudu 20,19, 18, dan 17 pada pengujian tersebut diperoleh 4 kurva berbeda, dan harga efisiensi sistem yang berbeda pula. Diketahui bahwa semakin cepat putaran variasi sudu maka harga efisiensi sistem akan semakin bertambah, kemudian jika sudah mencapai harga maksimal, maka harga efisiensi sistem akan menurun meskipun harga putaran semakin bertambah, sehingga membentuk kurva melengkung dari awal hingga akhir.
Berdasarkan data pengujian tersebut diperoleh harga efisiensi terbesar berturut-turut adalah $22,664 \%$ pada putaran 880,148 rpm oleh sudu 20 , sudu 18 efisiensi sistemnya sebesar $21,76 \%$ pada putaran 965,730 rpm, 21,35 \% pada putaran 974,540 rpm oleh sudu 17, dan sudu 19 efisiensi sistemnya sebesar $20,826 \%$ pada putaran 965,730 rpm.

\section{Karakteristik Daya Mekanik $\left(P_{m}\right)$ terhadap Putaran (n) pada perbandingan nosel lingkaran dan nosel persegi}

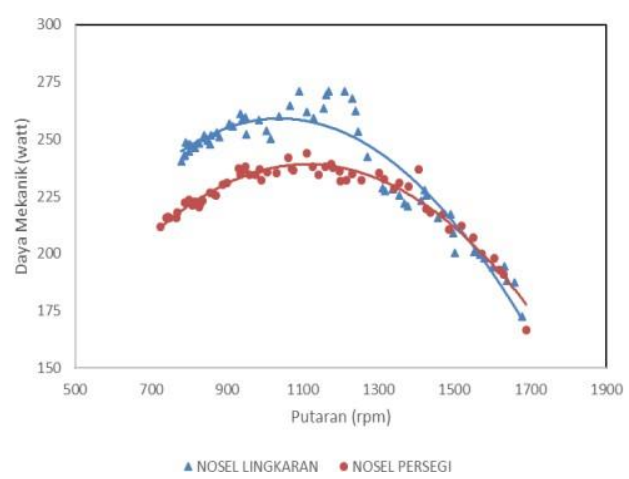

Gambar 16. Grafik Hubungan Daya

Mekanik terhadap Putaran pada Sudu 20 dengan Perbandingan Antara Nosel Lingkaran dan Nosel Persegi

Gambar 15. dibawah ini, menunjukkan karakteristik hubungan daya mekanik terhadap putaran pada sudu 20 dengan perbandingan saat menggunakan nosel lingkaran dan nosel persegi. Terlihat bahwa pada kurva tersebut, semakin cepat putaran yang dihasilkan maka daya mekanik yang dihasilkan akan semakin bertambah hingga mencapai titik puncak, kemudian daya mekanik akan mengalami penurunan meskipun jumlah putaran semakin bertambah.

Pada kedua kurva perbandingan diatas diperoleh harga daya mekanik paling optimum adalah sebagai berikut berturut-turut :

1. Daya mekanik maksimum untuk sudu 20 pada nosel lingkaran sebesar 259,378 W, dengan jumlah putaran sebesar 1040,637 rpm.

2. Sedangkan harga daya mekanik maksimum sudu 20 pada nosel persegi sebesar 238,113 $\mathrm{W}$, dengan jumlah putaran sebesar 1110,696 rpm.

Berdasarkan data tersebut daya mekanik maksimum untuk sudu 20 terbesar terjadi pada saat menggunakan nosel lingkaran. Meskipun begitu, terlihat pada grafik tersebut,, kerapatan harga hubungan daya mekanik terhadap putaran terbaik terjadi pada psaat menggunakan nosel persegi. Hal tersebut terjadi karena penurunan 
putaran pada setiap beban saat menggunakan nosel lingkaran lebih teratur dari pada saat menggunakan nosel persegi.

\section{KESIMPULAN}

Berdasarkan pengujian dan analisa variasi jumlah sudu mangkuk dengan perbandingan saat menggunakan nosel lingkaran dan nosel persegi, diperoleh harga daya mekanik, daya generator, efisiensi generator, dan efisiensi sistem. Data yang diperoleh menunjukkan bahwa pengujian saat menggunakan nosel lingkaran memiliki kinerja terbaik pada saat variasi jumlah sudu mangkuk ketimbangsaat menggunakan nosel persegi,berikut ini harga parameternya,

1. Daya mekanik maksimum perbandingan antara nosel lingkaran dan nosel persegi dari variasi jumlah sudu yaitu 20, 19, 18, dan 17 terbaik adalah pada sudu 18 menggunakan nosel lingkarandiperoleh daya mekaniknya sebesar 261,722 W pada putaran 851,754 rpm, dan daya mekanik tererdah terjadi pada nosel persegi yaitu pada sudu 19 sebesar $228,999 \mathrm{~W}$ pada putaran $1086,85 \mathrm{rpm}$.

2. Daya generator maksimum perbandingan antara nosel lingkaran dan nosel persegi dari variasi jumlah sudu yaitu 20,19, 18, dan 17 terbaik adalah pada sudu 20 menggunakan nosel lingkaran diperoleh daya generatornya sebesar 145,537 W pada putaran 1076,043 rpm, dan daya generator terendah terjadi pada nosel persegi yaitu pada sudu 19 sebesar 123,047 W pada putaran 970,231 rpm.

3. Efisiensi generator maksimum perbandingan antara nosel lingkaran dan nosel persegi dari variasi jumlah sudu yaitu 20, 19, 18, dan 17 terbaik adalah pada sudu 18 menggunakan nosel persegi diperoleh efisiensi generatornya sebesar $59,78 \%$ pada putaran 1037,76 rpm, dan efisiensi generator terendah juga terjadi pada nosel persegi yaitu pada sudu 17 sebesar 48,07\% pada putaran 973,959 rpm.

4. Efisiensi sistem maksimum pada perbandingan saat menggunakan nosel lingkaran dan nosel persegi dari variasi jumlah sudu yaitu 20,19, 18, dan 17 terbaik adalah pada sudu 20 menggunakan nosel lingkaran diperoleh efisiensi sistemnya sebesar 22,664 \% pada putaran 880,148 rpm, dan efisiensi sistem terendah terjadi pada nosel persegi yaitu pada sudu 19 sebesar $18,97 \%$ pada putaran 970,282 .

\section{DAFTAR PUSTAKA}

Anagnostopoulos, J.S., dan Papantonis, D.E., 2008, Flow Modeling and Runner Design of Optimization in Turgo Water Turbines,
International Journal of Applied Science Engineering and Technology 4;3.

Bono, dkk. 2010. Karakteristik Unjuk Kerja Turbin Aksial Terhadap Variasi Jumlah Sudu Untuk Pembangkit Listrik Tenaga Mikro Hidro.

2012. Kajian Eksperimental Turbin Turgo dengan Variasi Sudut Nozzle. Jurnal Teknik Energi. Volume 8, No. 1. Semarang.

---------. 2012. Optimasi Daya Turbin Turgo dengan Variasi Jumlah Sudu dan Sudut Nosel untuk Pembangkit Listrik Tenaga Picohidro.

Dwiyanto, Very., dkk. 2016. Analisis Pembangkit Listrik Tenaga Mikro Hidro (PLTMH) Studi Kasus: Sungai Air Anak (Hulu Sungai Way Besai) JRSDD, Edisi September 2016. Volume 4, No. 3. Jurusan Teknik Sipil Fakultas Teknik Universitas Lampung.

Endardjo P, Warga Dalam J, Setiadi A. 1998. Pengembangan Rancang Bangun Mikrohidro Standar PU. Bandung: Prosiding HATHI.

Fox, Robert W dan Alan T.Mc. Donald. 1994. Introduction to Fluid Mechanics, fourth edition. SI Version, John Wiley \& Sons, Inc. Canada.

Harvey, Adam et al. 1993. Microhydro Design Manual, Intermediate Technology Publication London.

Hendar dan Ujang. 2007. Desain, manu-facturing dan instalasi turbin propeller open flume $\emptyset 125$ Mm di C.V. Cihanjuang Inti Teknik Cimahi-Jawa Barat. Bogor: Fakultas Teknologi Pertanian IPB.

Hsb, Muhammad Syawal Al-Azhar dkk. 2017. Pengujian Karakteristik Turbin Pelton dengan Sudu 15 dan 16 Skala Laboratorium. Jurusan Teknik Mesin, Sekolah Tinggi Teknik Harapan Medan.

Ismono H.A. 1999. Perencanaan Turbin Air Tipe Cross Flow untuk Pembangkit Listrik Tenaga Mikrohidro di Institut Teknologi Nasional Malang. Skripsi

Lestari, Agus., dkk. 2017. Modifikasi Bentuk Sudu Turbin Turgo untuk Pembangkit Listrik Tenaga Mikrohidro. Tugas Akhir. Semarang: Jurusan Teknik Mesin.

Morong, Juneidy Yohanes. 2016. Rancang Bangun Kincir Air Irigasi Sebagai Pembangkit Listrik di Desa Talawaan. Tugas Akhir. Manado: Program Studi Teknik Listrik Jurusan Teknik Elektro Politeknik Negeri Manado.

Nasir, Bilal Abdullah. 2013. Design of High Efficiency Pelton Turbine for Microhydro Power Plant. Hawijah Technical Institute. Iraq. 
Nugraha, I.N.E., dkk. 2013. Penerapan dan Analisis Pembangkit Listrik Tenaga Pikohidro dengan Turbin Propeller Open Flume TC 60 dan Generator Sinkron Satu Fasa 100 VA di UPI Bandung. Jurnal Reka Elkomika. Volume 1, No.4. Bandung

Setiawan, Budi., dkk. Tanpa tahun. Unjuk Kerja Turbin Air Tipe Crossflow dengan Variasi Debit Air dan Sudut Serang Nosel. Tugas Akhir. Pangkalpinang: Jurusan Teknik Mesin Universitas Bangka Belitung.

Tampubolon, Frans Ade Putra . 2014. Uji Performansi Turbin Pelton dengan 26 Sudu Pada Head 5,21 Meter Dengan Menggunkan Satu Buah Nosel dan Analisa Perbandingan Menggunakan Variasi Bentuk Sudu . Departemen Teknik Mesin, Universitas Sumatera Utara.

Utomo, Agaza Dwi, Sentono Aji dan Ulin Setyawan, 2014. Rancang Bangun Turbin Turgo dengan Variasi Diameter Piringan untuk Pembangkit Listrik Tenaga Picohidro. Tugas Akhir. Semarang: Jurusan Teknik Mesin Politeknik Negeri Semarang. 